\title{
Some Remarks on Adaptive Phonetic Changes of Arabic and Persian Loanwords in Daghestanian Languages
}

\section{Abstract}

The paper deals with Arabic and Persian loanwords in Daghestanian languages. Adaptive phonetic changes and possible semantic deviations are investigated.

Keywords: phonetic change, phonetic adaptation, Iranian loanwords, Daghestanian languages

Numerous loanwords from Arabic and Persian went into vocabulary of Daghestanian languages, especially into Lezgian subgroup often through Azeri. They underwent various phonetic changes which will be briefly characterized below.

In many Persian and Arabic loanwords vocalism was preserved unchanged, but original long vowels are rendered as short vowels, even in these languages in which vowel length can be distinctive in native lexemes, ex.:

Bagv. insan $\leftarrow$ Arab. insān "man"; Tab. $\chi$ alq $\leftarrow$ Arab. xalq1 "people"; Ud. fikir $\leftarrow$ Arab.

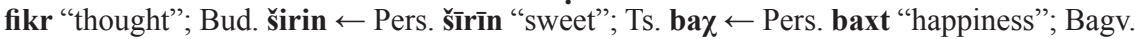

adam $\leftarrow$ Pers. ādam "men"

However, in some other instances vowel shortening was not accomplished, ex.:

Arch. izārṭu / izārbu, where izār- $<*$ azār $<*$ hazār $\leftarrow$ Pers. hazār "thousand"

On the other hand it is not excluded that -ā- in Archi was not inherited, but could have been shifted from the initial syllable, if it is supposed that: izār- $<*$ azār$<* \overline{a z a r}-<*$ ahzar- $<*$ hazar- $<*$ hazār-, where the vowel lengthening can be explained as the compensatory process after metathesis of the initial syllable and disappearance of the laryngeal spirant. Examples taken from other Daghestanian languages point out that such an explanation seems quite plausible, comp.:

Lezg. ahzir $<*$ hazir [metathesis]

${ }^{1}$ Phonetic transcription of Arabic words according to E. Lipiński, Języki semickie rodziny afroazjatyckiej. Zarys ogólny, Poznań, 2001, p. 86. 
Tab. aszur $<*$ ahzur $<*$ ahzar $<*$ hazar shows metathesis of the initial syllable. The second variant Tab. āzur $<*$ a $\mathbf{3} z u \mathbf{r}$ presents compensatory vowel lengthening after deletion of the uvular fricative consonant.

Quite parallel sound changes can be postulated for the above quoted Archi form.

In Rutul gunah < *gunāh $\leftarrow$ Pers. gunāh "sin", where original Classical Persian pronunciation of the first syllable was retained, comp. [gonāh] in contemporary Iranian Persian.

Despite Arabic and Persian vowels are known in all Daghestanian languages, they underwent various other changes apart from shortening in loanwords.

In some languages secondary nasal vowels were developed from phonetic groups with a vowel in prepausal or anteconsonantic position [vN\# / vN-C], ex.:

Tscham. wațã $<*$ wațan $\leftarrow$ Arab. wațan "homeland"

Khin. gardã $<*$ gardan $\leftarrow$ Pers. gardan "neck"

Khin. pä džärä <*pändžärä $\leftarrow$ Pers. pandžare "window"

Akhv. sapũ $<$ *sapun $<$ *sabun $<$ *sābun $\leftarrow$ Arab. șābun "soap"

In some languages secondary pharyngalization of vowels is encountered in phonetic neighbourhood of pharyngeal or laryngeal consonants which can be interpreted as an assimilative process having progressive or regressive direction ex.:

Tsakh. hašạrat $<*$ hašarat $\leftarrow$ Arab. ḥašārat "insects" [distal perseverative assimilation]

Tsakh. ạạl $<*$ aqal $\leftarrow$ Arab. aqal "reason" [contact perseverative as well as anticipatory assimilation]

Tsakh. hạkim $<*$ hakim "physician" $\leftarrow$ Arab. hakim "wise man" [contact perseverative assimilation]

Tsakh. šạhạr $<*$ šahar $\leftarrow$ Pers. šahr "town" [contact perseverative as well as anticipatory assimilation]

Although this process seems to be especially frequent in Tsakhur, its traces can also be found in other languages, ex.:

Lak ạdat $<$ * Cadat $\leftarrow$ Arab. 'adat "custom" [contact perseverative assimilation]

The part of Lezgian languages shows so called umlaut-vowels in the same as aforementioned phonetic circumstances, ex.:

Khin. gidžgäh $<$ *gidžgah $<$ *gidgāh $\leftarrow$ Pers. gidgāh "temple"

Khin. hädät $<*$ hadat $<*$ Sadat $\leftarrow$ Arab. 'adat "custom"

Anaptyctic vowels appear sometimes, especially in auslaut syllables, where consonant groups are not permitted for phonotactic reasons, ex.:

Ud. fik ${ }^{\mathbf{i}} \mathbf{r}<* \mathbf{f i k r} \leftarrow$ Arab. fikr "thought";

Tsakh. šạhar $<*$ šah ${ }^{a} \mathbf{r}<*$ šahr $\leftarrow$ Pers. šahr "town"

Rut. šähärä $<*$ šah ${ }^{\mathbf{a}}$ ra $<*$ šahra $\leftarrow$ Pers. šahre "way"

Somehow different type of anaptyxis shows ex.:

Tin. $\mathbf{z a h}^{\mathbf{u}} \mathbf{r}<*$ zahr $\leftarrow$ Arab. dahr "poison"

Botl., Ghod. azar ${ }^{\mathbf{u}}$ da $<$ *azarda, where: azar- $<*$ hazar- $<*$ hazār- $\leftarrow$ Pers. hazār "thousand", where anaptyctic vowel is -u-, albeit -a- would be more expected, taking into account the fact that in the other here quoted examples 
anaptyctic vowel harmonizes with the remaining ones. However, in some instances contextually conditioned changes can be involved as ex.:

Tsakh. to $\chi^{\mathbf{u}} \mathbf{m}<*$ to $\chi \mathbf{0} \mathbf{m}<*$ to $\chi \mathbf{m} \leftarrow$ Pers. toxm "family"

Centralization of articulation of high back vowel: $\mathbf{u}>\mathbf{i}$ is confirmed in several instances, ex.:

Khin. džadigar $<*$ džadugar $\leftarrow$ Pers. džāādugar "sorcerer"

Khin. pil $<$ *pul $\leftarrow$ Pers. pul "money"

Tsakh. bistan $<*$ bustan $<*$ būstān $\leftarrow$ Pers. būstān "orchard"

Various other quite rare phonetic processes pertaining to vowels can be observed in some other languages as for instance:

a) assimilative labialization under influence of preceding labial consonant, ex.:

Agh. burunz $<*$ burundz $<$ *burund $\check{z}<*$ burendž $<*$ berendž $\leftarrow$ Pers. berendž "(uncooked) rice"

The vowel of the second syllable underwent labialization as a result of the distal perseverative assimilation: $\mathbf{u}-\mathbf{e}>\mathbf{u}-\mathbf{u}$. Similar assimilations are also visible in some other loanwords, ex.:

Rut. tu $\chi \mathbf{u m}<*$ to $\boldsymbol{\chi} \mathbf{u m} \leftarrow$ Pers. to $\boldsymbol{\chi} \mathbf{m}$, comp. also Tsakh. to $\chi \mathbf{u m}$ "family" $[\mathbf{o}-\mathbf{u}>\mathbf{u}-\mathbf{u}]$

Ud. umud $<*$ umid $\leftarrow$ Pers. umid "hope" $[\mathbf{u}-\mathbf{i}>\mathbf{u}-\mathbf{u}]$

b) Secondary vowel lengthening is attested in one example from Khinalug, where:

kōna $<*$ kohna $<*$ kohan $\leftarrow$ Pers. kohan "old".

In this case the vowel lengthening can be elucidated as compensatory process after disappearance of the laryngeal spirant $\mathbf{- h}-$.

More attention should be drawn to one example from Krits, namely:

mi $\chi$ / me $\chi \leftarrow$ Pers. mix "nail"

It can be disputable, whether the variant me $\chi$ can be simply derived from $\mathbf{m i} \boldsymbol{\chi}$ (or maybe conversely) or the two forms were borrowed in different chronological periods and represent two different stages of the development of Persian. If it is true, the first variant mi $\chi$ should be regarded as the older one, comp. also Modern Persian mex from older Classical Persian mix.

Diphthongs were in some instances preserved in their original shape, ex.:

Av. haywan $\leftarrow$ Arab. ḥaywān "animal"

Arch. žawhar $<*$ džauhar $\leftarrow$ Arab. džauhar "jewel”,

but sometimes they underwent assimilative changes, ex.:

Ud. meymun $<*$ maymun $\leftarrow$ Arab. maymun "monkey",

where the change -ay- $>$-ey- consists in anticipative assimilation.

Bezh. bazay < *bazar < *bāzār $\leftarrow$ Pers. bāzār "market" draws particular attention. In this word the diphthong appeared secondarily because the auslaut sonorant -r was from synchronic point of view wrongly identified with morpheme 
of the IV grammatical class: baza-r. This morpheme can sometimes change into: $-\mathbf{r}>\mathbf{- y}$ or $-\mathbf{r}>\mathbf{- n}$ as it is the case in the word in question. ${ }^{2}$

A parallel morphological change is attested in Bezh. haza-y $<$ haza-r "thousand".

Monophtongization of diphtong is testified in Rut. qimat $<*$ qiymat $<*$ qaymat $\leftarrow$ Arab. qaymat "price". The similar process took place in most other Daghestanian languages, ex.:

Av., Hunz., Tab. or Bud. qimat $<*$ qiymat $<\ldots$, etc. (comp. above).

According to G. A. Klimov and M. Sh. Khalilov this word can be borrowed directly from Azeri gijmät "price". ${ }^{3}$ Such an explanation does not seem convincing, because the word in question is attested in almost the same phonetic shape in various Daghestanian languages from Avar-Andi-Dido and Lak-Dargwa subgroups. Azeri language can exert more intense influence only on Lezgian subgroup. Moreover, from phonetic point of view it would be quite strange to suppose that Azeri g- was rendered as pharyngeal abruptive q-.

Although consonant systems in Daghestanian languages are quite rich, such sounds as for example emphatic consonants typical to Arabic are not known. What can seem astonishing, they are not identified with geminates, but in some languages are rendered by respective abruptives, ex.:

Agh. $\chi$ at $\leftarrow$ Arab xaṭ "line". 4

In other languages they can be identified with usual aspirated obstruents, ex.:

Kr./Bud. $\chi$ et $\leftarrow$ Arab. xat "line"

As for Arabic emphatic spirants, they usually are rendered by (aspirated) non-emphatic and non-geminated spirants, ex.:

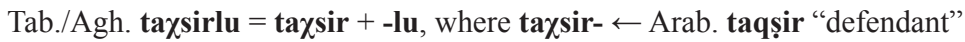

Bud. sabun $<*$ sābun

However, gemination of spirant is observed in some languages, ex.:

And. s:apun $<*$ s:abun $<*$ s:ābun

Tin s:apĩ $<*$ s:apin $<*$ s:apun $<*$ s:abun $<*$ s:ābun $\leftarrow$ Arab. șābun "soap"

It seems quite interesting that voiceless aspirated plosive consonants can be rendered as voiceless abruptive or geminated consonants ex.:

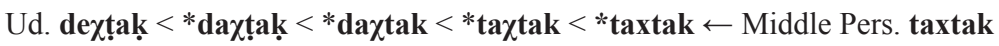

Tab. t:a $\chi \mathbf{t}: \mathbf{a} \leftarrow$ Middle Pers. taxtak "board"

Khin. esk:är $<*$ ask:är $<*$ askar

Ud. äsḳär $<*$ askar $\leftarrow$ Arab. askar "soldier"

This fact convincingly proves that not aspirated but abruptive or geminated members of phonological oppositions are treated as the marked members.

${ }^{2}$ N. Ardoteli, Bezhta Language: Grammar, Texts, Vocabulary, Tbilisi 2010, p. 38.

3 Г.А. Климов, М.Ш. Халилов, Словарь кавказских языков. Сопоставление основной лексики, Москва 2003, р. 271.

${ }^{4}$ According to traditionally accepted conventions [t] is emphatic consonant in Arabic and abruptive voiceless plosive in Daghestanian languages. 
Phonological glottal constriction, so called hamza, was not preserved in anlaut position but it is rendered variously in intervocalic position. In some languages can be retained without changes, ex.:

Arch. s:a?at $<*$ sa?at

Khin. sä?ät $<*$ sa?at $\leftarrow$ Arab. sa'at "hour"

However, in many others hamza went into voiced [\$] or voiceless laryngeal spirant [h], ex.:

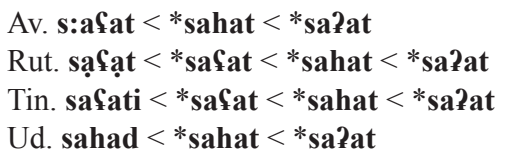

The forms with voiceless laryngeal spirant should be regarded as more archaic from the point of view of relative chronology. The sound change $\mathbf{- h}-\mathbf{>} \mathbf{- \mathbf { f }}$ - can be interpreted as sonorization of the spirant in consequence of its lenition in the intervocalic position.

Sometimes hamza disappeared entirely, ex.:

Lezg. sät $<*_{\text {sat }}<*_{\text {saat }}<*_{\text {sa2at. }}$

Secondary sonorization of voiceless laryngeal spirant: $-\mathbf{h}-\mathbf{-}$-\$- - can be encountered in some languages as for instance in Krits and Khinalug:

Kr. maSsul $<*$ mahsul

Khin. mä؟sul $<$ *ma§sul $<*$ mahsul $\leftarrow$ Arab. maḥsul "harvest"

Disappearance of implosive consonant segments, especially in final syllables can be encountered in some examples, ex.:

Dar. $\operatorname{ta} \chi<* \operatorname{ta} \boldsymbol{\chi} \mathbf{t}<* \operatorname{tax} t<* \operatorname{taxtak} \leftarrow$ Middle Pers. taxtak "board"

Ts. ba $<<$ *bax $<*$ baxt $\leftarrow$ Pers. baxt "happiness"

Ud. gam $<*$ garm $\leftarrow$ Pers. garm "warm" shows dissimilative disappearance of one sonorant in the phonetic sequence: $-\mathbf{R R}>-\mathbf{R}$.

Consonant clusters in final syllables are not permitted in Daghestanian languages and this phonotactic constraint can easily elucidate abovementioned sound changes.

An assimilative process can be observed for example in:

Tscham. azalla $<$ *azal-da $<$ *azar-da $<$ *hazar-da $\leftarrow$ Pers. hazār "thousand".

It is the case of anticipative assimilation of the dental resonant and voiced dental plosive:

-rd- > -ld- > -ll-

This change goes even further in Hinukh, where the final syllable, being unstressed, was apocopated:

fazal $<$ * azal-la $<$ * Gazal-da $<$ * Cazar-da $<$ *hazar-da

Addition of an epithetic segment in auslaut is rarely attested, ex.:

Darg. džind $<*$ džin $\leftarrow$ Arab. džin "bad ghost" 
Since epithesis belongs to so called irregular phonetic changes, it is impossible to clarify its causes.

Simplification of alveolar affricate: $\mathbf{d z ̌}$ - $>$ ž- can be encountered in numerous languages, ex.:

Lezg., Tab. žiger $<*$ žigar $<*$ džigar "lung" $\leftarrow$ Pers. džigar "liver"

Botl., Ghod. žanaza $<$ *džanaza $<*$ džanāza $\leftarrow$ Pers. dženāze "dead", "corpse"

Arch. žauhar $<*$ džauhar $\leftarrow$ Arab. džauhar "jewel"

Such a phonetic change is quite natural because in consonant systems of Daghestanian languages voiced velar affricate [dž] is not known or has not phonological status and occurs mainly in foreign words.

Methathesis of phonetic segments is attested in few instances, ex.:

Ud. arbeš:um $<*$ abreš:um $<$ *abrešum $\leftarrow$ Pers. abrešum "silk"

Lezg. ahzir $<*$ ahzar $<$ *hazar $<$ *hazār $\leftarrow$ Pers. hazār "thousand"

Abovementioned sound changes are most probably caused by phonotactic constraints, but it is not possible to solve this question in detail at current state of the knowledge. Phonotactics of Daghestanian languages still requires further investigation. ${ }^{6}$

It is beyond doubt that above presented examples and their investigation can only be a very tentative attempt at describing and explaining of adaptive phonetic changes in Persian and Arabic loanwords in Daghestanian languages. These problems seem to be very interesting and require further meticulous research.

\section{Abbreviations}

Agh. - Aghul

Akhv. - Akhvakh

And. - Andi

Arab. - Arabic

Arch. - Archi

Av. - Avestan

Bagv. - Bagvalal

Bezh. - Bezhta

Botl. - Botlikh

Bud. - Budukh

Darg. - Dargwa

Ghod. - Ghodoberi

Hin. - Hinukh

Hunz. - Hunzib

Khin. - Khinalug

Kr. $\quad-$ Krits

${ }^{5}$ It seems that primary meaning of this word can be reconstructed as "internal organ". Semantic differentiation "lung" :: "liver" should be regarded as a later secondary process.

${ }^{6}$ C. Baramidze, Phonological Structure of Tabasaran, Tbilisi 2009, p. 3. 
Lezg. - Lezgian

Middle Pers. - Middle Persian

Pers. $\quad-$ Persian

Rut. $\quad-$ Rutul

Tab. $\quad-$ Tabasaran

Tin. $\quad-$ Tindi

Ts. $\quad-$ Tsakhur

Tscham. - Tschamalal

Ud. $\quad-$ Udi

\section{Bibliography}

Ardoteli N., Bezhta Language: Grammar, Texts, Vocabulary, Tbilisi 2010 [in Georgian].

Baramidze C., Phonological structure of Tabasaran, Tbilisi 2009 [in Georgian]. Lipiński E., Języki semickie rodziny afroazjatyckiej. Zarys ogólny, Poznań 2001.

Климов Г.А., Халилов М.Ш., Словарь кавказских языков. Сопоставление основной лексики, Москва 2003. 